\title{
Transfers and Implementations of a Swedish Manual Work Program: Sloyd and Entrepreneurial Power
}

\section{Martin Lawn}

Sloyd, a Swedish handwork programme for schools, beginning in the late years of the 19th century, was influential in Sweden but almost immediately it began to influence teachers and educators from other countries. This influence is explored in this paper. Using transnational historiography, the sites of influence, and the flow of people and texts, is explored. The focus here is on the circulations of ideas and practices between states, and in particular, between Sweden, the US, the UK and India, and the particular ways in which this flow and embedding of Sloyd occurred. The paper is about Sloyd and about the conditions underlying its influence in other countries, broadly from the 1890s to the 1930s, although its effects continued to roll out across the world after this period.

In the late 19th century, a national innovation in education, Sloyd, flourished in Sweden and almost immediately was transplanted to other countries, eventually establishing a community across the world, from India, the USA to New Zealand. When an educational innovation moves out of its home context, it is described as an «influence» and, as such, its presence appears fleetingly. Using Sloyd as a case, the intention is to "dissect» the actual processes through which innovation travels, becomes embedded and finally fragments or is discarded. A transnational history approach has a concern for the places of production, reproduction or translation as well the "spaces» between» In Saunier's terms: «it is an approach that focuses on relations and formations, circulations and connections, between, across and through these units, and how they have been made, not made or unmade» (2013, p. 2).

Sloyd [in its anglicised spelling] was a programme of handwork or creative woodwork designed for schools to introduce into their curriculum as a fully formed and equipped modernization. Although very well organized, it is not clear how it had such a major effect on the idea of education and schooling across widespread sites. Using ideas from transnational history, the Sloyd movement will be analysed in terms of its core technologies and particularly its use of texts, exhibitions, training sites, and communications, its partisans and its 
codified methods. In addition, Sloyd is seen here not only as a form of organized diffusion but as a form which adapted itself to diverse conditions and combatted alternative versions of manual training. Most of all, its success was shaped by its entrepreneurial nature and early support from the Swedish state.

This paper is organized in the following order: firstly, a further description of the key ideas of a transnational history approach; Swedish education presented in world fairs in the late 19th century; the site of Sloyd training; American and English experience; the role of students worldwide; experience in India; and finally, a lingering decline and what can be learned from this case about influence and transnational effects.

\section{Transnational}

In general, when studying transnational effects, there are open questions to be asked about what is circulated or exchanged, through what kind of pattern of motion, driven by what impulse, by what mediating components and within what favourable or constraining conditions? To understand how the Swedish programme flowed into new national sites and practices, and came to be seen as a solution to local practices, the key elements of this process have to be clarified. For national histories, Sloyd is a national occurrence; an event bounded by period and how it emerged into the national case takes second place to the advance of the local system into modernization. Historians have generally built their work upon that of previous generations, and using their key "framework of analysis», the nation-state (Iriye, 2013, p. 2), and the focus was on how the state emerged and developed. The idea that the nation state couldn't be understood except as situated within movements in world history, gradually required linkages with scholarship in the economic, trade, financial, and diplomatic areas. It remained intact as a key unit of analysis though. The importance of international policy and research communities working in education, and their rich intertwined influence on the construction of national policies and practices, the movement of pedagogic objects and routines, and their role in international organizations is the approach used here in the study of Sloyd across borders. This works its way out in the focus on "cross national connections, whether through individuals, non-national identities, and non-state actors, or in terms of objectives shared by people and communities regardless of their nationality» (Iriye, 2013, p. 15).

Following the transnational movements of ideas, practices, objects and people means that they should be studied within a de-centred context. Understanding the elements of movement and human and material interaction emphasises the production of mix, blend and hybridity in the diverse forms of «migrations, cultural transfers and interchanges» they engage in (Iriye, 2013, p. 78).

Saunier has summarized this approach in the following way, which is worth quoting at length: 
First is the historicization of contacts between communities, polities and societies. Here the goal is to study how the exchanges and interactions waxed and waned, to appraise the changing, the levels of exchange, integration and disintegration between the territorialized basic units of historical understanding [countries, regions, continents]; and to give empirical answers to the questions of what is, and when was globalization.

Secondly, the transnational perspective acknowledges and assesses foreign contributions to the design, discussion and implementation of domestic features within communities, polities and societies; and, vice versa the projection of domestic features into the foreign...

Thirdly, transnational history deals with trends, patterns, organizations and individuals that have been living between and through these self-contained entities that we use as units of historical research. Here we have an opportunity to recover the history of projects, individuals, groups, activity processes and institutions that have often been invisible or at best peripheral to historians because they thrived in between, across and through polities and societies. (Saunier, 2013, p. 3)

So, it is with the entity, and in this case we start with Sweden, that we study the wax and wane of its influence and connections, the hybrid and composite in its construction and governance, and the complexity of these processes, over time. The range of conceptual tools which we can use include the following. Firstly, the connectors: the intermediaries and brokers, all actors working with texts and guides, and create regulations and standards, all items which structure mobility and interconnection (Saunier, 2013)

[Connectors] enter or create situations where they can act as go-betweens, they use certain mechanisms and tools to accomplish their connecting performance, they are active in one region, or one moment, and not in another, they make ties and unmake them. (Saunier, 2013, p. 57)

Secondly, the situations that "connectors» work across may vary from major events, like exhibitions, major research projects and informal meetings. Travel and related problems are the basis of their work, and inquiry, conversation and analysis are its fundamentals. Part of that work is about comparison.

Thirdly, they travel and leave a trace, and sometimes, assemble in or create circuits. They meet, correspond, publish, translate, convene and generally produce circulations.

\section{Sweden at the Fair}

Its Swedishness - as a location, language and specific practice - was initially problematic but eventually became its distinctive feature. Sweden was not one of the big industrial countries which were expected to represent the advantages 
of their education system alongside their leading industrial status. Yet it did have a track record of educational innovation, its entries in the World Exhibitions in the 70s, especially at the Philadelphia Centennial in 1876, with a model Schoolhouse, were very influential (Lundahl \& Lawn, 2015). Alongside Sloyd, the simultaneous promotion of Swedish gymnastics, the Ling method, were also persuasive within other national education systems. Comparison was an important element in the states' education policies and in their use of the International Exhibitions. Also, national advantage in industrial competition was important. Suspicions about the particularity of system innovations and even their «foreignness» was a problem to be overcome. So, the «foreignness» of Sloyd could be initially challenging but not a hindrance to its success. For example, criticism that:

Sloyd is a foreign element and that it cannot be adapted to American schools ... the so-called foreign element should disappear if the system is successfully modified to the condition of this country, making it an American system based upon the same universal educational principles. (July 18, 1892, p. 3 Boston Evening Transcript)

Seventeen years later, the same newspaper described the Sloyd exhibits at the Boston Exposition in 1909 «a pictorial and graphic description of the beginning and development of Sloyd, its spread from Boston to foreign countries» (Boston Evening Transcript, November 8, 1909, p. 16). The adoption and acclimatization of Sloyd and its representation as a local innovation and practice took place in many countries that moved beyond the role of receptor, but Boston was a major example of this process. What was Swedish and foreign about Sloyd became local through the work of agents and texts, and could even become nationally embedded elsewhere.

The idea and the practice of Sloyd emerged out of investigation and comparison: first by the Finnish educationalist, Cygnaeus, in 1858, who observed school systems in Sweden, Scotland, Germany and the Netherlands, and then by Salomon in Sweden but, based upon the work of Cygnaeus through a visit and letters. While Finland became a leading country of handwork, it is the work of Salomon that established the Swedish method as world idea and practice, beginning nationally but flowing across borders. Sloyd in Sweden started as a movement for training in home industries and crafts (Salomon, 1892a). It had no direct educational significance and varied from area to area, depending on the purposes of their local, private sponsors. Salomon's version of Sloyd, established on his uncle's estate at Nääs near Gothenburg, included modern school subjects and a particular focus for boys on wood-sloyd, and for girls, on weaving and cookery. As his school turned towards producing Sloyd teachers from class teachers, the widening of the curriculum necessitated an agreement with the folk high schools. This shift from a vocational to an educational purpose led to the growth of vacation courses for teachers, and further, permanent short courses. 
Over the course of ten years, the Nääs school grew from a local vocational course of useful crafts into an educational movement, operating nationally but becoming increasingly attractive to teachers from abroad. At the outset, Swedish Sloyd was an interpretation and a revision of Finnish ideas.

Briefly, Sloyd is not all it appears to be, that is, a system of school woodworking. Although it involved woodworking and the use of tools, especially the Sloyd knife, it was designed as a material form to produce a progressive way of thinking, a moral outlook and independent learning. In Salomon's plan, it was not vocational education or a preparation for skilled employment. In fact, it was produced in opposition to mechanical industries (Molander, 1902) and mass, routinized education. Salomon offered an account of an entirely new system of education, which, although graded and closely observed, was about values and the education of the person (Salomon, 1892a). Its roots were in humanistic education and references were made to its connections to Rousseau and Froebel. Salomon's keywords were respect, independence, self-reliance, attention, a sense of form and these terms were used as chapter headings and followed by detailed ways in which they could be achieved. This made the works of Salomon stand out from the educational literature of the time, which concentrated on values at the expense of practical pedagogy. The Sloyd programme was a pedagogical exercise, focused on the capabilities and interests of the individual children. In Salomon's words, it aimed to instil a love of work, training in habits of order, exactness and perseverance, promotion of physical powers, and to train the eye and exercise thinking (Larsson, 1902). For the elementary teacher, often faced with very large classes and few resources, this was essential:

A more rational course in Sloyd was worked out by one for whom I entertain the highest regard. [It is to Salomon] that the educational Sloyd movement in Sweden and other countries owes its greatest advancement and greatest value. (Larsson, 1902, p. 15)

It is the melding of graded, practical work with a philosophy of learning which appealed to many audiences, but especially elementary school teachers. It attracted new educationalists and industrial and vocational trainers (via its Froebelian roots, see Brehony, 1998). This was traded upon in the International Exhibitions where audiences were mixed. Larsson, a key disciple reported that:

At the 1893 Chicago World Fair ... the Froebelian idea of harmonious development of the child could be combined with the utilitarian needs of the industrial society, and that students working with materials and tools derived great satisfaction from making useful objects. (Dobbs, 1970)

Common to many national and sectorial interests in the late 19th century was the establishment of an elementary, mass education system and its contents. Sloyd had a value beyond its actual claims and practice as it offered a well-organized plan and material resources in a practical or active form of curriculum in contradistinction to the common desk and rote based curriculum. 


\section{Place}

Even transnational influences have to be located in actual places, and the most significant place for Sloyd was from the start of Salomon's work and consistently Nääs. Nääs was a large country estate, east of Gothenburg, belonging to Salomon's uncle (August Abrahamson) who was a major sponsor and enthusiast for his work. The school at Nääs and its associated buildings became the physical home for Sloyd and closely associated with it. It was the site of national and international training, of official delegations and commissions, and the place from which Sloyd texts emerged. An English teacher, an early visitor to Nääs, said that "Varnum [the House of Friends], a large house on the estate was especially prepared for foreign visitors... an interesting custom prevails on the estate, of hoisting the flags of the different nations represented in the Sloyd school» (Whittaker, 2014, p. 54).

A London inspector, who wrote the preface for English translation of Salomon (1892a) wrote:

Nääs is a good Sloyd school, and much besides. It is the meeting place of leading teachers of all degrees and all nationalities, for common work, and for the interchange of ideas. Professors, inspectors, secondary and elementary teachers, women as well as men, there meet on common ground as comrades. It fulfils, more than any other institution that could easily be named, the ideal we are aiming at in England. (Hooper, cited in Salomon, 1892a, p. XI)

Another English teacher, who became a joint secretary of the Sloyd association in England, described Nääs in this way: "The mixture of nationalities and languages, the simplicity of the mode of life, the early hours, the general kindliness, the absence of class distinctions, the child-like enjoyment of little pleasures, the good tempered rivalry in work» (Whittaker, 2014, p. 65).

Every summer at Nääs, Salomon lectured in English and German to the many foreign attendees. So, Näs was not an incidental place but a magnet, a place for imagining the possibilities of Sloyd, and associated with the pleasure of learning. Apart from Swedes, the largest group, students came from all over the world to study there: primarily from England, Scotland, Norway, the USA, Germany and Holland. Many other countries were represented over a twenty-year period: for example, groups from Siam, Greece, Russia, Romania, Austria, and individuals from Argentina, Cape Colony, Abyssinia and the Philippines (Bjerke, 1916, cited in Whittaker, 2014, p. 83).

Foreign visitors and teachers deepened the proselytizing impulse at Nääs to find ways to extend the ideas and practices of Sloyd and Salomon's books were translated or synthesized and published in many countries. Salomon was a great publicist for Swedish or Nääs Sloyd. His lectures were written to engage with varied audiences - school teachers in different countries, the experienced Froebelian and kindergarten teacher, those who persisted with direct instruction, and systems which had been built out of ad hoc elements. 
His first book Handicraft School and Elementary School was «sent to a large number of supporters of handicraft teaching throughout the Nordic countries» (Thorbjörnsson, 2006, p. 16). The Teachers Handbook of Sloyd (1891) [English edition translated from Swedish a year after publication] was a detailed handbook about the objects, tools and programmatic processes of Sloyd, and it acted as the core book of the movement, the discursive version of the Nääs course. It was followed by The Theory of Educational Sloyd (in 1898).

Further, Salomon was an authoritative and influential letter writer. His notes on handwork books and articles appeared in his monthly newsletter [the teacher's sheet]. His texts in newspapers and from lectures were translated into English, and sometimes into German, French, Spanish, and Russian among others. In turn, his supporters wrote their own books about Sloyd, according to Thorbjörnsson (2006) over a hundred were produced across Europe and South America, and hundreds of articles in magazines and newspapers as well. A fast growing labour market in Nääs trained teachers was an outcome of this media driven offensive.

Salomon also travelled widely in Europe to discuss his ideas with leading thinkers and practitioners in Germany, Denmark, the Netherlands, Italy, Austria, England and France (Thorbjörnsson, 2006). At the same time, he was building a network of Sloyd converts, who treated Nääs, his work and his methods as the centre of their work, and their mission. Soon it was not a question of where Salomon went or where his ideas were published or re-published in translation but what his major «disciples» were writing and doing. For example, Sluys in Belgium gave a series of lectures around the country and a report for the Belgian government, which was influential in England, France and the US. If they had attended Nääs courses, there was a good chance that they would become Sloyd champions, and Thorbjörnsson mentions a range of principals and inspectors across the world in this role, sometimes working across a sequence of countries. Salomon appears to have been able to place his teachers, by request, into key positions in national systems of education, especially in South America.

Apart from texts, letters and travels, a major innovation by Salomon was to extend the influence of Sloyd by using the World Exhibitions to display his work and ideas. Abrahamson, his uncle, sent models, plans, tools and information about Nääs to the 1876 Centennial Exhibition in Philadelphia but failed to make a big impression, unlike the full-scale model of a Swedish Schoolhouse, which was very influential. Determinedly, they aimed to make a stronger impression at the World Exhibition in Paris in 1878 and Abrahamson sent a description of Nääs Sloyd schools to several Swedish ambassadors in Europe and an invitation to their country's delegate to the Nääs stand in Paris (Thorbjörnsson, 2006). He also offered to donate Sloyd models and provide further information about Nääs and educational Sloyd.

By the time of the 1900 Paris Exhibition, Hjalmar Berg, the Stockholm craft inspector (and later Director of the Swedish School Museum) and the organizer of the Swedish school, exhibits in Paris. 
Even during a brief stroll through the various departments, one received a strong impression of the great influence that Nääs has had on handicraft schooling. One clearly saw how even in the most diverse countries, Swedish educational sloyd has served as a paragon. /.../ Sweden's influence is most apparent in the exhibitions from Russia and Austria-Hungary, as well as from some English schools and the famous American-Swede Gustaf Larsson's Sloyd institute in Boston. Close ties with Swedish educational sloyd could be witnessed in the Finnish and Norwegian exhibitions. (SLUB 1901, cited in Thorbjörnsson, 2006, p. 20)

Nääs exhibited in St Louis in 1904 and at «other international exhibitions in Greece, Chile, Algeria» (Whittaker, 2014, p. 35).

Transnational history reveals and orders the way in which influence is created. Salomon was just a traveller, the most common way in which education histories describe early national actors, but he was a connector, joining Nääs to wider audiences through his texts, his lectures and teaching.

He generated key actors in other countries, who then built networks which inserted core standards of operation, of pedagogy, in their sites. These networks were both independent and inter-dependent, interconnected through the agreed ways of understanding Sloyd and regulated by their shared texts.

\section{American and English Experience}

So, Sloyd was propelled by the ambition and hard work of Salomon through the Nääs education centre, his translated texts, his European travels and discussions, and the displays at World Exhibitions. Within a short time, Sloyd was no longer a Swedish-centred school project but a rapidly growing cross-border and cross-sea modernizing practice proselytized and claimed by many other educators. Visits to Nääs were often followed by local proselytising by Sloyd disciples and the creation of national associations and journals, and sometimes by new educational ordinances and the provision of grants for Sloyd adoption in schools. One of the most important of the Sloyd evangelists was Gustaf Larsson, a Nääs trained Swede who travelled to Boston and settled there. In 1888 he travelled to Boston, and with the support of the philanthropist Mrs Agassiz Shaw, he started a handicraft school for children and a college, Boston Sloyd Training School, where for over twenty years he trained around 400 teachers, who then went on to teach in the Americas. At the Columbian Exposition in Chicago in 1893, Gustaf Larsson exhibited school work from his Sloyd school in Boston, and gave a speech which contrasted the Sloyd system with the Russian system of manual training. At the 1902 St Louis Exposition, he was even more ambitious and the display included photographs, original models, texts and pamphlets (Sloyd Record 1.1, 1904). His philanthropic sponsor, Mrs Agassiz 
Shaw exhibited Sloyd work from Boston at Chicago, Paris and St Louis, and was awarded the Grand prize (Eyestone, 1989).

Larsson modelled himself on Salomon and his successful tools: texts, travels and exhibitions. In 1896, Larsson travelled across Europe, and in particular to the leading German manual training institute in Berlin, as well as to Birmingham, Manchester and London. The English technical instruction organizing secretary, Badger, had produced a report distinguishing between manual training and Sloyd. "[He paid] high tribute to Sloyd, which also has many other enthusiastic advocates in England. Large numbers of English teachers go yearly to Nääs to take the course there and get inspiration of Herr Salomon's lectures» (Larsson, 1902, p. 54).

Larsson advanced new arguments about Sloyd, faced with a situation in which Russian manual training had grown in influence since the Philadelphia Centennial Exhibition. He constantly distinguished, especially in the US, Sloyd from manual training, the more commonly used American expression, and also from Russian influenced manual work. For Larsson, as for Salomon, Sloyd was a means to a wider moral, aesthetic and mental development. The Russian method seemed to limit itself to American ideas of manual work, focusing as it did on repetitive skill training and exercises. Sloyd, Larsson argued, is very different in approach: «It is based upon the Froebelian idea of the harmonious development of all the powers of the child, tools and exercises being chosen with reference to this end, and all merely mechanical methods being carefully avoided.» (Larsson, 1902, p. 23)

This argument, that Sloyd is neither a form of vocational training nor an early apprenticeship for industry, had to be stressed more in the US and Larsson did so constantly. Larsson also produced what he called American Sloyd. Salomon's principles stayed intact but the conditions in which they had to operate were different and Larsson took the agreed Swedish progression of exercises and tools and added the objects of interest to an "American boy» (Larsson, 1902, p. 17). Later he went further than Salomon, allowing children who had attained was on the learning process and not overly on the finished product (Eyestone, 1989).

Boston became a new hub for Sloyd. A Canadian Commissioner visited the Boston training schools and set up a trial of the «Boston methods» in Canada. The Macdonald Fund in Canada then equipped 12 provincial Sloyd centres (Boston Evening Transcript, January 8, 1900, p. 5). The same year three Cuban teachers studied in Larsson's school for a year. A complete Sloyd tool centre was sent to Cuba with the Boston proviso that the: «Models of the course have been changed to suit the requirements of the Cuban people so as maintain the idea, strongly emphasised in the American system, of adapting the principles to practical work». (Boston Evening Transcript, November 26, 1900)

Across the US, the Boston influence was felt when ex-students introduced Sloyd into Wisconsin, North Carolina, Los Angeles and Portland, for example.

The distinction between principles and context or between Sloyd and Russian style manual training was important. Variation was accepted but deviation was 
opposed fiercely. A Dane had created a local variation, Danish Sloyd, and was described by Salomon as a heretic (Whittaker, 2014).

The influence of an idea or practice across borders on depends on the practice itself, as well as on the perceived need or problem in the host country. There was a tension around handwork, handicraft or manual skills in English schooling, as the 1862 Revised Code focused on key subjects, that is, reading, writing and arithmetic. Central government payments to the school depended upon tested progress in these subjects. At the same time, there was a tension around education as influential industrialists and middle class «policy actors» demanded a useful education, that is, with practical skills useful for manual employment. Although there were local experiments in technical education and a growing Froebelian activity based education movement, there was no impact upon the conservative Department of Education in London. As manual work was not an agreed part of the curriculum, it could not be supported by public money. A private grant enabled pilot projects which, being successful, allowed manual work to be officially recognized and, by 1890, training centres were set up and the subject could be discussed (Robertson, 1899).

In England and Scotland, gifts of money by private individuals and guilds enabled educational reformers to give the system a fair trial at many centres. During the decade now closing it has been taken up and extended by School Boards with the co-operation and financial support of the Department of Education. (Robertson, 1899, p. 25)

Salomon addressed the National Union of Teachers annual conference in 1890 on manual training, a sign of the urgency of action. A tension arose, as in the US, between the manual/vocational training approach and the Sloyd handwork/ educational approach. "In 1891, 145 schools were giving instruction in manual work, in 1899, there were 1587 schools, and in 1910, 4261 schools» (Birchenough, 1938, p. 315).

However manual training was usually undertaken by craftsmen in special manual instruction centres, and viewed as a technical subject, both anathema to the Nääs school. Yet Sloyd appeared to be a solution to how the schools and teachers could develop manual work in the elementary school curriculum and the Board of Education's 1897 definition saw manual work, in the Sloyd way, as a «disciplinary exercise destined to train hand and eye to accuracy and to due appreciation of form» (Prideaux, 1914, p. 151). The shortage of handwork teachers meant that the English Board of Examinations for this subject began, in 1898 , to standardize the examinations and began to issue certificates for different aspects of handwork for example, kindergarten work, clay modelling, cardboard work, school gardening, etc. (Prideaux, 1914). The new Sloyd converts were often closely connected to the Froebel Society and sometimes slipped between education and technical training arguments, and even national achievements. The Froebel kindergarten was seen as an institution for manual training and 
training in the use of tools and Salomon was viewed as building upon Froebel thinking. Froebel and Sloyd became caught up in England with the threat of industrial competition, modernization and national survival. Hand and eye training was associated with the new education, and in turn with a new skilled working class (Brehony, 1998).

\section{Nääs Students}

Every student was treated as a budding emissary for Sloyd and the Nääs way. According to Bjerke (in Whittaker, 2014, p. 83) by 1917 there had been 8952 students attending Nääs trainings, drawn from 40 countries. Local newspaper accounts suggest that they established systems in their own countries, sometimes a training school, or perhaps influenced a policy document.

John Byatt, for example, a Londoner and elementary school teacher, went to Nääs, taught and became an examiner, and then applied, in 1900, for a post in Victoria, Australia as a qualified manual training instructor. A few years later, he became inspector of manual training and began to establish training centre. He lectured in other Australian states and published on Sloyd and modelling (Drummond, 1979).

In other cases, the students themselves published and were reported. In 1889, New Zealand hosted a World Fair [the New Zealand and South Seas Exhibition] in Otago which was visited by over half a million visitors over six months. The Fair had four special courts running parallel to the main avenue, one of which was the Education Court. In its first bay, the Kindergarten bay, there was a Sloyd bench for kindergarten carpentry classes. The New Zealand Herald described this «Swedish invention and useful apparatus», which alongside other educational exhibits, would prove to other colonial visitors that New Zealand education "does not lag behind in the progressive march of nations» $(\mathrm{NH}$, 1889). A sister paper, the Otago Witness, followed its statement that a great deal of interest was taken in the Sloyd system to explain at length its ideas and practices (OW, 1889). Two years later, another New Zealand paper, the Bush Advocate, referring to a recent edition of the New Zealand Times, discussed the Sloyd system at length, and referenced two teachers in London - Nystrom and Chapman. In particular, they focus on their approach: «[They] do not advocate the adoption of the Swedish system but insist on the necessity of having a method of manual training adapted to English habits and English forms and customs.» (BA, 1891, p. 2)

This is a paraphrase of point 2 in the objects of the Sloyd Association, formed in London in 1888, of which Nystrom and Chapman were the Honorary Secretaries. They were tireless advocates of Sloyd in England after they trained in Nääs.

In Denmark, Aksel Mikkelsen took a summer course in Nääs, and was then encouraged by Salomon to establish Sloyd in Denmark. In 1895 he established 
his own Sloyd training school. Within a short space of time, Mikkelsen began to develop a divergent variation of Sloyd. For example, he built his system on class instruction and not individual guidance; and it was based on the saw and not the knife (Thorsteinsson, Olafsson \& Yokoyama, 2009). Most of all, Sloyd was seen as a preparation for post school labour. His influence in Denmark, through its Sloyd association, encouraged the Danish government to establish Sloyd as a subject in school. In fact, Denmark had two rival schools of Sloyd, one following Nääs, and the other developing a Danish variant (Whittaker, 2014). Through the close connections between Denmark and Iceland, the first Icelandic student was sent to work with Mikkelsen in 1890 and then returned to teach the Danish Sloyd approach in Iceland. Some years later, a Sloyd teacher in Reykjavik, trained in Nääs, was made the Sloyd tutor in the new teacher college (Ólafsson \& Thorsteinsson, 2009).

One can see in these cases the willing audiences for Sloyd and forms of manual training and how practices moved across national sites, each of them having diverse contexts and purposes. Even a well organised innovation could create alternative or disruptive practices and over time, very different operations.

\section{Experience in India}

Most students at Nääs supported themselves or were sponsored by their governments. But this could go further and Sloyd became part of state system. The Inspector-General of Education in Mysore, DR HJ Bahbha, had visited several Sloyd schools in Europe and America and had chosen the Boston Sloyd school as the most "desirable system" for India (Journal of Education, 1907, p. 108). Following which, Larsson was invited to Mysore in India for a 6 month visit to establish Sloyd in its public schools and its training processes. He travelled from London to Bombay on July $14^{\text {th }}$ in a relatively small boat. This took approximately 3 weeks - four days to Gibraltar, then to Marseille, Suez, Aden and Bombay. To travel to Bangalore in Mysore was a further 745 miles by train.

Twenty male teachers had been «summoned» to Bangalore (p. 16) for the Sloyd course. They were graduates and experienced teachers - «they showed an aptitude, skill and interest quite equal to the American and European teachers» (p. 17). Larsson had sent over drawings of the Sloyd bench and twenty-one benches had been made locally. In addition to lectures on the principles and history of Sloyd, Larsson gave the same class as he gave in Boston teachers. A class of male school pupils was attached to the course so the teachers could test out the methods and tools in a classroom setting. He made the point that Sloyd's methods should always be adapted to existing conditions (p. 19). So, for example, he explained the differences between the American softwoods he used in Boston and the Indian hardwoods that were available in Mysore. A consequence of the course was that ten equipped Sloyd centres were established across Mysore, with 
tools ordered from Sweden, England and America. Larsson adapted Sloyd to local conditions - not the principles but the objects to be produced. Larsson saw himself as a cultural ambassador: he introduced Swedish gymnastics and found a way to subsidize modern Swedish literature for distribution in Mysore.

In 1912, the Bombay Government proposed replacing the system of manual training that was available in its training colleges and high schools, and replace it with the Sloyd system. A report in the Times of India about this decision said that Sloyd teaching in Mysore was successful, and that a Sloyd teacher from there should be invited to begin training classes at several sites across the region (Manual instruction as an educational subject, 1913). The following year, it was reported that the Sloyd supervisor in Bangalore had been seconded to Bombay for three years. During this period, he would «train two teachers from each Government secondary school and training institution", and subsequently they would establish Sloyd classes at five training colleges and five high schools, extending to the remaining schools if funding was provided (Auteur, 1914, August 14).

Again, as in India, Sloyd is adopted and reproduced as a necessary state policy. In 1897, the Commissioners in Ireland set up a special inquiry to determine if practical instruction could be included in the education system. Their report, known as the Belmore Commission report, was a thorough document which was used beyond Ireland, in Canada for example. For three months, the Commissioners drew evidence from a wide range of teachers, inspectors and staff of training colleges in Ireland, England, Scotland and in Europe. Otto Salomon was interviewed in Nääs by three of the Commissioners and observation reports were made on work in other European countries, a result of 93 meetings and of visits to Denmark, Germany, Switzerland, France and Holland.

The Sloyd innovation went through changes in the different settings in which it was established. This kind of laudatory welcome was not common in the 1890s:

We have been told, over and over again, that the introduction of manual and practical training has contributed greatly to stimulate the intelligence of the pupils, to increase their interest in school work, and to make school life generally brighter and more pleasant. As a consequence the school attendance is improved; the children remain at school to a more advanced age; and much time is gained for the purpose of education. (Royal Commission - Belmont Commission 1898, p. 5)

Its reputation continued to grow in India or Australia, for example:

Deputation of local parents to the Minister of Education «with a request that sloyd centres should be established at the school - in view of considerable growth of the district and the fact a 1000 pupils at the school made it an ideal centre». Minister said that the facilities would be provided but necessarily at that school. (The Age Melbourne, 1940, December 12, p. 6) 
Yet, gradually in some areas, and more swiftly, in other countries, it declined from the 1920s or became interpreted as a limited or «heretical» form of manual or vocation training.

\section{Aftermath}

Writing in the late 1930s, in his history of UK elementary education, Birchenough was sceptical about Sloyd and its effects, in spite of the fact it combatted the impractical character of schools. Although recognizing the Sloyd goals of dexterity, accuracy, ideas of form, and self reliance, he criticized it for its creation of an artificial idea of manual work, abundance of faith in hand-eye relations, and obsession with technique. Most of all, he argued against its lack of pupil goals and failure to meet their desire or need for practical purpose. More forcefully, he argued that «a standard of manual instruction was implanted on the country which seriously hampered progress» (Birchenough, 1938, p. 314).

His description of manual instruction classes where a class did the same work at the same time and worked through a graded set of models and used tools in the right sequence, and without freedom and initiative, and led by a craftsman [and not by a teacher, the Sloyd rule] implies that in the need to provide practical handwork teaching in the elementary school, a number of differing tendencies were at work. The Sloyd movement contributed to, and was implicated in, the critical failures of the time. Failures could be caused by conflicts with the country's own handicraft traditions, because obtaining handicraft benches was costly, because material was expensive or because politicians had different ideas about schooling (Thorbjörnsson, 2006). Sloyd was used to change the English education system, to widen it from deskwork into manual handwork, and brought together several arguments about the elementary education system and the working class. Its high period seems to have been 1880-1910. Even when its surge was over, it had served to widen the curriculum and opened it to woodwork. In Sweden, educational Sloyd changed because of internal school reforms in 1918 and 1919, and as a result of new vocational needs in trade and industry. As a system of education developed, Sloyd could become outmoded although its practices schools probably existed longer than its sponsorship by the state.

Sloyd's connection with, and use of, progressive, humanistic thought, in Pestalozzi or Froebel for example, combined with new vocational demands on schooling, created a tension in Sloyd and finally its demise in schooling. It lost allies, who once admired the combination of order and creativity but now saw mainly programmatic instruction:

Most fateful for the educational handicrafts movement was the critique that set in motion its decline in the United States, the United Kingdom and other countries at the turn of the century. Professor Stanley Hall and Colonel Francis Parker characterized the slöjd system as hyper-methodic and 
tyrannic, with its rigid course of models. They and others asked for creativity and training in the powers of imagination, for co-ordination between manual training and art, and for instruction based on projects for the children. (Hallstrom, 2009, p. 8)

Salomon and Larsson's attempt to hold the line on practice, order and learning as a modern solution to elementary education was faced with a fast developing progressive education movement and sharper employer demands on vocational outcomes in the period following the First World War.

The Sloyd movement was not a Swedish government initiative but, in its early days, its sponsorship was helpful at the International Exhibitions and Sloyd was featured as an example of modern Swedish school practice. The Swedish system did allow Salomon to flourish, as it did not constrain individual initiatives in teacher education or curriculum practice. At least, Salomon used the system, with the necessary private funding and enthusiasts, to devise a programme, train students and sell texts. The home of Sloyd innovation was situated in Sweden, at Nääs, and Sweden benefited by association with it.

Sloyd grew and flourished because it solved a problem, that of the narrow elementary curriculum: this problem emerged almost simultaneously with the growth of state mass schooling. The political demand for a limited [and cheap] education became in conflict with the changing need for a skilled workforce, and with an educationalist/ teacher led movement for a wider and creative curriculum. Sloyd was an idea and a practice, but most of all, it was a codified, discrete suite of texts and tools, implemented through a specific residential training course (Saunier, 2013). The students became converts and missionaries, establishing outposts in their countries, which sometimes developed into new hubs of production and influence. Although supported strongly by Salomon through extended European visits, Sloyd moved through a process of diffusion in which texts, face-to-face contacts, and objects all played a part and allowed an unrestrained movement into new sites and relations. English speaking conduits in travel and media helped this diffusion, especially across Imperial communication lines, but word of mouth allowed Nääs to grow consistently.

Sloyd generated powerful and consistent "connectors» not only with its key actors but also through every teacher who trained at Nääs. Enthusiastic teachers [and visitors as well] turned into «intermediaries and brokers» (Saunier, 2013, p. 34) or even disciples, as they travelled home, and across their regions and wrote for Sloyd conduits. They reinforced the ideas and the practices of Sloyd, justified local versions, and produced standardizations. Sloyd became something other than «Swedish» as it went «native» in other national contexts.

The Sloyd transnational networks seemed to have decayed before the national bases declined, that is when it was established outside Sweden, it continued as long as local conditions allowed. But the constant impetus needed to keep international linkages working began to decline after Salomon's death in 1907. From the 1890s until 1914, key «connectors» like Salomon and Larsson, used 
the International Exhibitions to display elements of Sloyd, to talk about it and meet interested teachers and managers. This period was also the high point of publishing about Sloyd. By the 1920s, dominant circulations and connections about Sloyd had become more regional and local. Sloyd meant a lot to its practitioners and often to a local authority or school board but this seems to have been generation limited.

Finally, Sloyd appears to have retreated back, in the main, to its Swedish base, but it had great effects upon school systems across the world.

Earlier, I asked what value a transnational history approach could bring to understanding the influence of Swedish schooling innovations, and Sloyd in particular, in crossing border contexts. There are several points of value. The idea of exchange and circulation is often missed or remains as footnotes in bordered histories, and so the travelling object, person or text is absent from interpretation. In this case, we can see patterns of diffusion by students and visitors to and from Naas, driven by a zeal to bring Sloyd to new schooling sites across the world. But the practice travels by text, by technology, by World Fairs and by lecture tours as Sloyd was a very well organized innovation. Although it originated in Sweden, it circulated so effectively that it became embedded at other national sites, all linked together by texts, news, community and through key "conductors» or mediators. Sloyd was a project. Private funding and some state support were helpful in establishing the base in Sweden and its organized dissemination, into international Exhibitions and displays. The period was important as the stage of development of elementary education, the rise of vocational education influences and the need to revise the curriculum in more established systems all pushed or pulled Sloyd as the system solution.

The Sloyd case, treated within a transnational frame, provides insights into the problem of «territorialized units of understanding», on their porous nature.

\section{Archives}

Manual instruction as an educational subject (1913, August 1). Royal Society of Arts Journal, 61(3167), 858-86. Retrieved from www.jstor.org/stable/41340762

Auteur (1913, June 14). Manual training: Bombay government action The Times of India, p. 10.

Auteur (1914, August 14). Schools in Bombay -Value of Manual Training. The Times of India, p. 5.

Auteur (1889, November 21). Titre de l'article. Otago Witness, p. 17. Retrieved from paperspast.natlib.govt.nz/newspapers/otago-witness]

Auteur (1889, November 27). Titre de l'article. New Zealand Herald, p. 5. Retrieved from paperspast.natlib.govt.nz/newspapers/new-zealand-herald

New Education System (1891, June 30). Bush Advocate, VII(488), p. 2.Retrieved from paperspast.natlib.govt.nz/newspapers/BA]

Auteur (1907, July 18). Boston University. Journal of Education, pp. 84-86. Retrieved from JStor [University of Edinburgh]

Auteur (1911, February 9). Boston University. Journal of Education, p.156. Retrieved from JStor [University of Edinburgh] 


\section{References}

Birchenough, C. (1938). History of Elementary Education in England and Wales (3rd ed.). London: University Tutorial Press.

Brehony, K. J. (1998). «Even far distant Japan» is «showing an interest»: the English Froebel movement's turn to Sloyd. History of Education: Journal of the History of Education Society, 27(3), 279-295.

Dobbs, S. (1970). The visual arts in American education The Journal of General Education, 22(2), 105-121.

Drummond, N. (1979). Byatt, John 1862-1930. Australian Dictionnary of Biography, 7. Retrieved from http://adb.anu.edu.au/biography/byatt-john-5456/text9267

Eyestone, J. E. (1989). The influence of Swedish Sloyd and its interpreters on American art education. Unpublished Dissertation, University of Missouri.

Eyestone, J.E. (1992). The Influence of Swedish Sloyd and Its Interpreters on American Art Education. Studies in Art Education, 34(1), 28-38.

Hallström, J. (2009). Technical knowledge in a technical society: elementary school technology education in Sweden, 1919-1928. History of Education: Journal of the History of Education Society, 38(4), 455-474.

Iriye, A. (2013). Global and Transnational History: The Past, Present and Future. New York, NY: Palgrave Macmillan.

Larsson, G. (1902). Sloyd. Boston, MA: [publisher unknown].

Lundahl, C., \& Lawn, M. (2015). The Swedish schoolhouse: a case study in transnational influences in education at the 1870s world fairs. Paedagogica Historica, 51(3), 319-334.

Molander, A. (1902). Scientific Sloyd. Syracuse, NY: Bardeen Press.

Ólafsson, B., \& Thorsteinsson, G. (2009). Design and Craft Education in Iceland, Pedagogical Background and Development: A literature review. Design and Technology Education: An International Journal, 14(2), 10-24.

Prideaux, E. B. R. (1914). A Survey of Elementary English Education. London: Blackie.

Robertson, J. W. (1899). Manual Training in Public Schools. Ottawa, Canada: The Macdonald Sloyd School Fund.

Royal Commission on manual and practical instruction in primary schools under the Board of National Education in Ireland - Final Report, House of Commons 1898 (C.8923) XLIV, 25. p5

Salomon, O. (1892a). The Theory of Educational Sloyd (Authorized, Revised and Edited by an Inspector of Schools, TG Rooper). London: Philip and Sons.

Salomon, O. (1892b). The Teacher's Hand-Book OfSlöjd. Boston, MA: Silver, Burdett \& Co.

Saunier, P.-Y. (2013). Transnational history. New York, NY: Palgrave Macmillan.

Thorsteinsson, G., Ólafsson, B., \& Yokoyama, E. (2014). The Establishment of Danish School Sloyd and the Beginning of Sloyd Education in Iceland. Bulletin of Institute of Technology and Vocational Education, 11, 85-94. Retrieved from http://hdl.handle.net/2237/20878

Thorbjörnsson, H. (2006). Swedish educational sloyd - an international success. Tidskrift för lärarutbildning och forskning, 2(2), 10-33.

Whittaker, D. J. (2014). The Impact and Legacy of Educational Sloyd. Abingdon, England: Routledge.

Keywords: Handwork or creative woodwork, Sloyd movement and influence, transnational history approach 


\section{Transfer und Implementation eines schwedischen Programms für den Handarbeitsunterricht: Sloyd und die unternehmerische Kraft}

\section{Zusammenfassung}

Sloyd war ein schwedisches Programm für den Handarbeitsunterricht, das am Ende des 19. Jahrhunderts eingerichtet wurde. Es hatte zunächst einen grossen Einfluss in Schweden, schnell aber auch bei Lehrern und Pädagogen in andern Ländern. Dieser Einfluss steht im Vordergrund des vorliegenden Beitrags. Ausgehend von transnationalen historiographischen Forschungsansätzen analysiert er sowohl die Orte, die vom Programm beeinflusst wurden, als auch die am Transferprozess beteiligten Personen und die entsprechenden Referenztexte. Der Fokus liegt einerseits auf der Zirkulation von Ideen, speziell zwischen Schweden, den USA, dem Vereinigten Königreich sowie Indien, andererseits auf der speziellen Art und Weise, wie diese Transfers und Bezugnahmen erfolgten. Die Analyse zielt also auf das Programm Sloyd und die Rahmenbedingungen, die es erlaubten, andere Länder zwischen 1890 und 1930 zu beeinflussen; das Programm erzielte nach dieser Periode allerdings auch weltweite Wirkungen.

Schlagworte: Handarbeitsunterricht, Wirkung der Sloyd-Bewegung, transnationale Geschichte

\section{Transferts et implémentations d'un programme suédois de travail manuel: Sloyd et le pouvoir entrepreneurial}

\section{Ré sumé}

Sloyd est un programme suédois de travail manuel pour les écoles mis en place à la fin du $19^{\mathrm{e}}$ siècle. Ce programme a eu une grande influence en Suède d'abord, puis très rapidement, auprès d'enseignants et d'éducateurs d'autres pays. C'est cette influence qui est au cour du présent article. Recourant aux apports de l'historiographie transnationale, le présent article étudie les sites d'influence ainsi que le flux des personnes et de textes y relatifs. L'accent est mis sur la circulation des idées et des pratiques entre les États et en particulier entre la Suède, les États-Unis, le Royaume-Uni et l'Inde, ainsi que sur les manières particulières dont ces transferts ont été intégrés au projet Sloyd. L'analyse porte donc sur le programme Sloyd et sur les conditions qui ont permis son influence dans d'autres pays entre 1890 à 1930 en particulier, bien que ses effets aient continué ensuite à se déployer à travers le monde.

Mots-clés: Travail manuel et activité créatrice, mouvement et influence du programme Sloyd, histoire transnationale 


\section{Trasferimenti e implementazioni di un programma di lavoro manuale svedese: Sloyd e il potere imprenditoriale}

\section{Riassunto}

Sloyd è un programma svedese di lavoro manuale per le scuole creato alla fine del $19^{\circ}$ secolo. Il programma ha avuto una grande influenza prima in Svezia, poi si è diffuso molto rapidamente verso insegnanti ed educatori di altri paesi. È proprio di tale influenza che il presente articolo rende conto. Utilizzando i contributi della storiografia transnazionale, l'articolo esamina i luoghi d'influenza e il flusso di persone e di testi correlati. L'accento è posto sul flusso di idee e di pratiche intercorse tra i diversi Stati e, in particolare, tra Svezia, Stati Uniti, Regno Unito e India, nonché sui modi particolari in cui tali trasferimenti sono stati integrati al progetto Sloyd. L'analisi si concentra quindi sul programma Sloyd e sulle condizioni che hanno portato alla sua influenza nei vari paesi in particolare tra il 1890 e il 1930, sebbene i suoi effetti abbiano continuato a diffondersi in tutto il mondo.

Parole-chiave: Lavoro manuale e attività creativa, movimento e influenza del programma Sloyd, storia transnazionale 
